\title{
Criticism of the Police in the News
}

\author{
Discourses and Frames in the News Media's \\ Coverage of the Norwegian Bureau for \\ the Investigation of Police Affairs
}

\author{
Ester Pollack \& Sigurd Allern
}

\begin{abstract}
Mediated descriptions of reality are tremendously important to the way the public - and policymakers - perceive the police. The present article analyses how leading news outlets reported and commented on complaints against the Norwegian police during the period 2005-2008. The study is based on content analyses of press and television coverage, with special emphasis on a publicly debated police action in which a student of African origins lost his life. In most cases, news coverage of the police and the investigators of the police is event-driven, and the picture of the police seldom points to institutional or organizational problems. The story is too often one about individual wrongdoings alone. Unfortunately, such media pictures matter and influence policy decisions, especially when they become the point of departure for political debate.
\end{abstract}

Keywords: policing, crime news, framing, complaints, racism

\section{Introduction}

Mediated descriptions of reality are tremendously important to the way the public - and policymakers - perceive the police. The news media is the primary information source for discussions about crime trends, criminal justice policy, law enforcement and police work. ${ }^{1}$ Public debates arise at regular intervals when a more critical spotlight is aimed at police work itself, normally focusing on individual missteps (rotten apples), including accusations of violations of the law and omissions by police officers, but seldom concerning system errors (rotten barrels). Such problems have resulted in the establishment of police oversight agencies in several European countries; the Police Complaints Commission (IPCC) in England is a well-known example.

Until the late 1980s, complaints against the police in Norway were investigated internally. Then, in 1988, in order to counter public criticism and make the police more accountable, Special Investigatory Bodies (SEFO) were established in the different State Attorney Districts (Thomassen 2002). Nonetheless, the system continued to be accused of not being independent of the regular police organizations. In an attempt to increase the public's confidence, the Norwegian Parliament decided to establish a new oversight agency with both investigating and prosecuting authority. To that end, in January 2005, 
the Norwegian Government established the Norwegian Bureau for the Investigation of Police Affairs to look into criminal offences in the conduct of police work. ${ }^{2}$ Although the new organization was organized as an independent agency, it was allowed to recruit former police officers as employees.

In March 2008, the Ministry of Justice and the Police ${ }^{3}$ appointed a temporary commission with the mandate to evaluate the control mechanisms concerning police work and the role played by the Norwegian Bureau for the Investigation of Police Affairs. ${ }^{4}$ The Official Norwegian Report (NOU 2009: 12) published the commission's evaluation and recommendations. One reason for this evaluation was the on-going, critical public debates about the control system, which became especially intense after a law enforcement action in Trondheim in September 2006, which resulted in the death of Eugene Obiora, an African-born student. A more general question in the public debate was linked to the well-known impression that charges or complaints are often filed against police officers, but that the police themselves are rarely fined, indicted or convicted. For example, on 20 September 2008, Aftenposten, one of Norway's leading dailies, had the following front-page headline: 'Rarely punished. The Bureau for the Investigation of Police Affairs drops nearly all its cases.' The failure of the Bureau to react quickly leads to questions of 'closing ranks' and insufficient distance between the police and investigators. Furthermore, accusations of police abuse and wrongdoing being treated with kid gloves are frequent.

Formally, because it is not part of the police service, the Norwegian Bureau has an independent position. However, many of its employees come from the police; consequently, de facto informal collegial relationships may exist. According to the Official Norwegian Report (NOU 2009: 80), although some of them had worked for other employers before they joined the Norwegian Bureau, all of the specialized personnel investigating complaints had (2008) a police background. Among the leaders of investigation (permanent staff lawyers), three out of four had worked previously as police officers or prosecutors, and among the headquarter staff, six out of ten had the same background. Filstad and Gottschalk (2011: 98) note that a majority of the investigators at the Norwegian Bureau are former police officers, and they cite the head of the Norwegian Bureau when he argues that it is necessary to have police expertise with experience and knowledge about the work methods and dilemmas of the profession - as well as staff from other professions with other kinds of expertise.

In the public debate, it is argued from the side of the police that several factors explain why around 90 per cent of the complaints are regarded as irrelevant (Filstad \& Gottschalk 2011: 106). From 2005 to 2010, a total of 60 police employees in Norway were prosecuted in court; 20 cases were dismissed from court and only four police officers were sentenced to more than 2 years imprisonment (Gottschalk 2011: 175). One apparent reason for the low number of relevant cases is that sometimes the investigation is routine, for example, following shooting episodes or traffic accidents involving police officers. Another reason is that criminals or other actors with a perceived wrong to avenge against police officers often lodge complaints. Although being subjected to this type of criticism is probably unavoidable in this line of work, the complaints are frequently found to be unfounded or the complainants overlook the fact that use of force by the police was legitimate in that particular situation. The head of the labour organization, the Norwegian Police Federation, has been a tireless advocate of this view in a 
number of debates on the topic in Norway. In an opinion piece in Dagbladet (15 May 2007), although he also mentions another factor, namely the importance of the media as a player in creating trust or suspicion, Tor-Geir Myhrer, a professor of police law, addresses this point as well. In his view, the Norwegian Bureau faces an impossible mission if its decisions not to prosecute are the only ones reported by the media.

The data presented in the present paper were gathered at the request of the temporary commission appointed by the Ministry of Justice to evaluate the Norwegian Bureau for the Investigation of Police affairs. The full report (Allern \& Pollack 2009) is printed as an appendix to the Official Norwegian Report (NOU 2009: 12). The paper focuses on news media coverage in cases where police officers have ended up in the public dock and become a matter for the Norwegian Bureau for the Investigation of Police Affairs.

Our research questions are directly connected to the issues mentioned above and are as follows:

- What kind of image of the Norwegian Bureau for the Investigation of Police Affairs is being communicated in news texts?

- How extensive and systematic is the coverage of the Norwegian Bureau and its cases in the press and on television?

- Which groups are the predominant types of sources in these news reports?

- What kind of complainant primarily receives media coverage?

- Is it primarily the Norwegian Bureau's decisions not to proceed and acquittals that receive public attention?

- What discourses characterized public debate on investigations of the police and activities of the Norwegian Bureau during the period 2005-2008?

\section{Changing Pictures of the Police}

According to journalistic norms, shining a critical spotlight on the role of the police as a public wielder of power is part of journalism's self-appointed 'societal mission'. In the history of journalism, the image of the police has swung between two poles that may be said to reflect the societal mission of law enforcement: between repression and security, between being the long arm of the law and serving the public, between controlling the citizenry (when behaviour is defined as undesirable or criminal) and serving the citizenry (Pollack 2008; Reiner 2010). Drawing on US crime reporting, Surette (2011: 84) sums up competing law enforcement frames of 'good cop' and 'bad cop'. In the good cop frame, the police represent a justice machine with dedicated professionals who use the latest technology to prove that crime does not pay. In the competing bad cop frame, the criminal justice system and its police are bound by regulations, corruption and incompetence.

Ordinary news reporting of police work is often limited to reporting about crimes and law enforcement, especially concerning violent and dramatic cases. The perspective is coloured by the fact that police departments are the key source for journalistic coverage concerning violations of the law. This has been true historically, but is also true today (Chibnall 1977; Dahlgren 1987; Ericsson et al. 1989; Pollack 1995 and 2001; Høst \& Bodahl-Johansen 2001; Surette 2006; Mawby 2010). Reports about crime, crime trends 
and judicial reactions are often based on information from police officers, and the chosen frames are influenced by open or anonymous police sources, especially in the first stages of a police investigation. Later, in the judicial process, lawyers will normally be alternative media sources, supplemented by victims and witnesses, sometimes also by criminologists and other experts.

Between journalists and sources, there will be both cooperation and conflict, 'a negotiation of control' (Ericsson et al. 1989) over the construction of the mediated pictures of policing. Reiner (2007) describes the relationship between the media and the police as one of 'mutual dependence and reciprocal reinforcement'. News is a representation of authority, and police sources often represent the authorized versions of reality. Nevertheless, news organizations and journalists simultaneously 'retain meaning making power' through their control of the final headlines and news texts (Carlson \& Franklin 2011: 6, Ericsson et al. 1989: 339).

Historically, this has led to widely shifting portrayals of and public debates on the role of the police. A typical Scandinavian picture of policing in the first decades after the Second World War was the portrait of the police as competent law enforcer. In the 1970 s, the pictures became increasingly disparate. The 'good cop' was a social worker, albeit with too few resources to do the job. A more troublesome figure, the 'bad cop' represented unnecessary violence and other types of misconduct. The professionalization of journalism gradually made the reporting more critical and independent. Later, starting in the 1990s, media reports emerged of a police force without the ability and resources to fight both new and international forms of criminality. Crime reporting, especially in the popular tabloids, also became more personalized and oriented towards using the victims of crime as witnesses and sources (Pollack 2001, 2008).

News stories of 'rotten apples' in the police force fit into the last-mentioned type of media reports. Generally, the news media focus is on crime and criminals, not the police. The exceptions are stories about wrongdoing by the police and police brutality (Surette 2011: 92). These cases often attract tremendous media attention and thus support the 'bad cop frame' and a negative impression of policing. In Los Angeles, in 1992, the Rodney King case became internationally known as a case of police brutality and racism when four white police officers struck and kicked him, a black man, whilst six other white police officers watched without reacting to stop the violence. The event was videotaped, shown all over the world and led to the LA riots (Marsh and Melville 2009: 125). Another well-known and debated case is the death of Ian Tomlinson in London in 2009. He died of a heart attack when he was walking home from the G20 London summit protests. In a police statement about his death the authors 'forgot' to include the fact that Tomlinson, shortly before he died, had been pushed to the ground by a police officer. This resulted in several days of false media coverage of the event. However, because 'ordinary people' had captured the event with their mobile cameras, it eventually led to questioning of the police version and later to a revelation about how the police force's own restricted interest had dictated the information given to the public (Jewkes 2011: 165; Davies 2009). Given its immediate influence on public debate and opinion, the death of Obiora (in Trondheim in 2006) represents a 'test case' of the same type. An interesting question is whether such cases also result in investigative reporting and a more critical analysis of more systemic problems and 'rotten barrels'. 


\section{Data and Methods}

To study the news media coverage in cases where the Norwegian Bureau investigates police officers, we conducted a content analysis of four leading newspapers. The content analysis covers the period from the formal establishment of the Norwegian Bureau for the Investigation of Police Affairs in January 2005 until the end of September 2008. The newspapers under examination include Norway's three largest circulation dailies, Aftenposten, VG and Dagbladet, as well as Adresseavisen, the leading newspaper in the Trondheim region. $V G$ and Dagbladet are popular tabloids, which generally give high priority to crime journalism. Aftenposten and Adresseavisen are both regional morning papers. Adresseavisen was included because the Obiora case in Trondheim was the most debated news story involving the police during the period covered by our study. A search in the news archive Avisarkivet Retriever/A-tekst for articles mentioning Spesialenheten for politisaker (Norwegian Bureau for the Investigation of Police Affairs) in the chosen period (January 2005 - 30 September 2008) resulted in 1503 hits regarding printed news sources, including news stories from NTB (the Norwegian News Agency). Of these articles, 58 per cent were published in the four newspapers represented in our study, illustrating that smaller local newspapers seldom give such stories priority.

All articles referring to Spesialenheten for politisaker (the Norwegian Bureau) in the four chosen papers were then included. PDF files of the actual news pages were purchased from a commercial company and then printed and coded. Using detailed coding instructions as a guide, a research assistant with experience in content analysis carried out the coding. ${ }^{5}$ A qualitative reading of selected articles related to some of the research questions supplemented the content analysis of the news texts. ${ }^{6}$

In addition, we registered all news items, mentioning Spesialenheten, broadcasted by the Norwegian public service television channel NRK1's main evening news programme (Dagsrevyen) and TV2's main evening news programme (TV2-Nyhetene). In doing so, we analysed every third item in which the Norwegian Bureau was mentioned during the period covered by our study. In addition, we studied recordings of three television debate programmes addressing cases with which the Norwegian Bureau for the Investigation of Police Affairs had dealt. ${ }^{7}$

Placing special weight on the predominant discourses and frames established through news stories, commentaries and television debates, in the last part of the article, we analyse the Obiora case.

\section{The Scope of Coverage and the Sources}

In the course of the 45 months covered by the study, the four newspapers printed 707 articles in which the Norwegian Bureau for the Investigation of Police Affairs was mentioned. Since the Bureau's work is rarely the main story, the registration and coding does not reveal how large a role the Norwegian Bureau plays in each article. What is most important in the news stories are the actions of the police and the complaints about and investigations of police officers.

When the articles are weighted by size and converted to tabloid pages, ${ }^{8}$ the breakdown is as follows: Adresseavisen, 105 tabloid pages; VG, 96; Dagbladet, 87; and Aftenposten, 54. In September 2006, the death of Obiora was the main news story and debate topic. In the period after he died ( 8 September 2006 - 30 September 2008), the related stories 
represented between 26-36 per cent of the weighted editorial in VG, Dagbladet and Aftenposten, and as much as 76 per cent in Adresseavisen. The two popular tabloids, $V G$ and Dagbladet, printed most stories about other cases involving the Norwegian Bureau. As mentioned above, popular tabloids generally give priority to 'law-and-order' news. However, even in these newspapers, there is no regular and systematic coverage of the Norwegian Bureau as a news beat. In all four dailies, news is the predominant genre, and although commentaries and debate articles are relatively frequent, features are nearly non-existent.

During the period under study, the two television channels combined had 123 items on the main news broadcasts in which the Norwegian Bureau was mentioned, 57 on TV2 Nyhetene and 66 on NRK1 Dagsrevyen. Most of the television reports aired in 2007 related to the Obiora case.

'Official sources' play a predominant role, with police and prosecuting authorities as the largest group (see Table 1). Together with spokespersons for the Norwegian Bureau, these source categories represent 41 per cent of all main sources. Lawyers are also a visible source type. The two tabloids, $V G$ and Dagbladet, are distinguished by having the largest proportion of 'grass-roots' sources, here defined as private persons without any particular institutional or organizational position. The main reason is that there was, in some cases, and especially related to Obiora's death, considerable civil and popular involvement - not least among young people - that was followed in the press. In ordinary news, this source category is usually less than 10 per cent (Allern 2001).

Table 1. Main Source in News and Feature Articles where the Norwegian Bureau for the Investigation of the Police is mentioned in 2005-2008 in Four Newspapers

\begin{tabular}{lrrrrr} 
& \multicolumn{5}{c}{ Newspaper } \\
Source category & VG & $\begin{array}{c}\text { Aften- } \\
\text { posten }\end{array}$ & Dagbladet & $\begin{array}{c}\text { Adresse- } \\
\text { avisen }\end{array}$ & All \\
\hline Police and prosecuting authority & 19 & 28 & 20 & 31 & 24 \\
The Norwegian Bureau & 19 & 17 & 10 & 20 & 17 \\
'Grass roots', activists & 32 & 9 & 41 & 8 & 23 \\
Lawyers & 20 & 16 & 17 & 10 & 15 \\
Spokesmen for civil organization & - & 1 & 1 & 8 & 3 \\
Politician & 3 & 1 & 3 & 3 & 2 \\
Other categories & 6 & 26 & 1 & 15 & 11 \\
No source reference & 2 & 2 & 7 & 6 & 4 \\
Sum & 100 & 100 & 100 & 100 & 100 \\
(N in 1000 square cm) & $(80.2)$ & $(42)$ & $(67.9)$ & $(85.4)$ & $(275.5)$ \\
\hline \multicolumn{7}{c}{ Cramer's V: 0.329 }
\end{tabular}

Note: Per cent of all articles (weighted).

Because cases affecting the Norwegian Bureau are seldom so politicized that they result in news stories in which policymakers are directly brought in, politicians are rarely used as sources. Even in the Obiora case, few politicians were engaged. As expected, the vast majority of the sources were men. Moreover, in the articles in the sample, one or more anonymous sources were used in an average of 20 per cent of the articles; there were more in the popular tabloids Dagbladet and $V G$, and fewer in the two regional 
dailies. Of these anonymous primary sources, many are quasi-identified as nameless representatives of the police.

\section{Critical Images of the Police}

Most news reports in question are about the actions taken by police officers that have resulted in accusations, criticism or criminal charges being filed and about responses to such criticism. The data consequently represent a limited and biased segment of media reports concerning the police service. In this case, the primary focus is on problems, scandals and the dark side of police work.

In their presentation and framing of news stories, journalists have to choose an angle, deciding the perspective and focus on an aspect of the story perceived to be important. This expression is related to the media studies concept of 'framing', specifically, the textual elements - especially headlines, introduction and pictures - that impress on the reader a certain interpretation of the nature of the story and tie it to a recognizable cultural or political narrative (Entman 1993; van Gorp 2007; Allern 2014).

Some of the news in the period under study involves well-known cases where the Norwegian Bureau routinely entered the picture, including reports of deaths during or following an arrest or of vehicle pursuits in which persons were injured or killed. One example is a shooting episode in Larvik, a small Norwegian city, on 18 May 2005, which was the first major case assigned to the newly appointed bureau. The police were called because a Vietnamese man, obviously mentally disturbed, was threatening people with a meat cleaver. He was pursued, but refused to lie down. Several shots were fired - one fatal. Both Kripos (the National Criminal Investigation Service) and the Norwegian Bureau were called in. On 20 May 2005, Aftenposten reported that the Bureau had assigned five investigators and three legal experts to examine the case. The newspaper added that all the special investigators were formerly with the police. However, Aftenposten made note of something else: 'in Larvik, the investigation is signalling its independence from the forces of law and order. Instead of setting up shop at the police station, investigators have checked into a hotel. There they interviewed more than 12 witnesses yesterday.'

The shooting attracted a great deal of attention, including a main story in $V G$ on 19 May 2005. In connection with the case, Dagbladet wrote an editorial (20 May 2005) in which the paper fundamentally discussed the problem of weapons having been made more readily available to police officers, a development the newspaper opposed. The story was presented with two very different angles in the respective papers. The $V G$ story from Larvik emphasized that the police officer who shot 'had no choice'. Dagbladet's top story in the Larvik case (19 May 2005) had a completely different angle, expressing the perspective of grieving friends: 'He didn't deserve to die.'

After this, there was no mention of the case in the papers until mid-July (16 July 2005), when Aftenposten and Adresseavisen printed a wire story from NTB, Norway's national news agency, reporting that the Norwegian Bureau for the Investigation of Police Affairs was dropping the case because the police in Larvik did not commit a criminal act. That decision was not mentioned in Dagbladet or VG. This illustrates another finding from our study: on the whole, the newspapers' coverage of the cases is unsystematic. In some instances, articles are published about matters that the Norwegian Bureau has decided to investigate, but then it is more random whether readers later learn about the 
Bureau's conclusion. In other instances, the Norwegian Bureau's decisions not to proceed - or its sanctions - are published in cases that did not receive previous mention.

In the content analysis, we included a variable telling whether the articles contain criticism of police and prosecuting authorities. When the answer was yes, we distinguished between articles where this criticism is an essential element directly expressed in the story or headline and articles where the criticism is only a subordinate element (e.g., as a critical interview statement in the body of the article). One typical example of a story with a critical main angle is a front-page headline in Dagbladet on 1 November 2005: 'Police scandal. Sold passports to criminals.'

Table 2. Does the Article Contain Critique of the Police/Prosecuting Authorities?

\begin{tabular}{lccccc} 
& \multicolumn{5}{c}{ Newspaper } \\
News Angle & VG & $\begin{array}{c}\text { Aften- } \\
\text { posten }\end{array}$ & Dagbladet & $\begin{array}{c}\text { Adresse- } \\
\text { avisen }\end{array}$ & All \\
\hline Yes, critical main angle & 55 & 37 & 57 & 30 & 45 \\
Yes, but limited critique & 22 & 34 & 13 & 27 & 23 \\
No & 23 & 28 & 30 & 42 & 32 \\
Sum & 100 & 100 & 100 & 100 & 100 \\
(N in 1000 square cm) & $(86.6)$ & $(49.2)$ & $(78.5)$ & $(94.7)$ & $(308.9)$
\end{tabular}

Note: Per cent of all articles (weighted) where the Norwegian Bureau for the Investigation of the Police is mentioned in 2005-2008 in four newspapers.

Two-thirds of the articles contain a strong or more limited critique. The articles without any critical elements are mostly information from the police or prosecuting authorities, including defence of police officers and more fact-oriented statements. The critical angle is clearest in the two popular tabloids, where more than half of the articles are in this category.

\section{'The Rotten Apples'}

Let us then look at the media coverage of some specific cases in which police officers are accused of personal violations of the law and are therefore under investigation.

As expected, a review of the news stories published before the Norwegian Bureau drew any conclusion reveals an image of the police service that is not particularly flattering. The following headlines illustrate the breadth of problems:

1. Police officers in Haugaland and Sunnhordland under investigation for selling police ammunition to civilians (TV2 Nyhetene, 19 October 2005).

2. Police stole and sold emergency passports ( $V G, 1$ November 2005).

3. Police officer charged with embezzlement (Aftenposten, 8 November 2005).

4. Police officer drove to work drunk (Dagbladet, 24 December 2005).

5. Police head under investigation: Had sex with woman in custody $(V G, 10$ November 2006). 
6. Drug lord warned after police leak ( $V G, 10$ September 2007).

7. Harassed female colleague regarding sex and religion ( $V G, 23$ November 2007).

8. High-ranking police officer demoted for sexual harassment (Adresseavisen, 22 February 2008).

Some of these cases received banner headlines and significant media coverage; others were only mentioned in short items. Even so, such personal violations of law and regulation represent only a small per cent of the news stories. Most of the covered cases deal more directly with the way in which police officers perform their duties, primarily with accusations and criticisms connected with this performance.

As mentioned, in the debate concerning the Norwegian Bureau's decisions, it is frequently noted that criminals are in the habit of complaining about/or filing charges against police officers 'who are only doing the job that society has given them to do'.

Although our material does not provide any basis for ascertaining the truth of this assertion, we are able to draw conclusions about the media coverage of such cases. Is it typical that those who receive coverage in the news media in such cases are themselves in conflict with the criminal justice system or the police?

After a systematic review at the article level, we have found very few examples of this. If we assume that a very large number of revenge charges are filed against the police, the conclusion must be that such cases rarely get any major media coverage.

Another question is how often the Norwegian Bureau for the Investigation of Police Matters is itself the subject of criticism in the news media. As could be expected, this happens to a far lesser extent than when the criticism concerns the police. Moreover, both directly and indirectly, a large number of these cases are connected to the Obiora case in the form of feature articles and opinion pieces.

The remaining criticism, aimed at the Norwegian Bureau on news pages, largely deals with long processing times, which are particularly irritating to the police service. Some examples include:

9. Spent two years on a police brutality case (unlawful arrest, ended with a corporate penalty for Asker and Bærum police district) ( $V G, 14$ August 2006).

10. Money crisis at the Norwegian Bureau; police cases gather dust ( $V G, 11$ November 2006).

11. Crisis of confidence in police investigators; 27 police chiefs raise the alarm $(V G, 28$ October 2007).

Such criticism is not of the system per se, but is due to the frustration over slow case processing time, which creates insecurity and uncertainty for the persons or unit under investigation.

In this context, it is rare for any direct criticism by the press to be directed towards government authorities. During the period under study, only eight stories in the four newspapers had a main angle critical of government authorities (four in Adresseavisen, three in Dagbladet and one in $V G$ ). In 24 other articles, there were some elements of criticism. This confirms the impression from the analysis of the sources: the media coverage of complaints and criminal cases involving police officers only occasionally reaches the political level. 


\section{Are Only Decisions not to Prosecute Covered?}

As previously mentioned, one of the research questions is whether the Norwegian Bureau primarily gets press related to cases being dropped and not related to police being fined or police organizations being given corporate penalties or being charged.

We have examined this issue by systematically reviewing all cases in the two tabloids, $V G$ and Dagbladet. Articles fall into roughly three categories: cases dropped, cases dropped along with forms of criticism, and criminal sanction or charge.

Some examples of articles about charges, indictments or criminal sanctions are:

12. Police officer's job was to uncover corruption. Now it is the officer who is charged (VG, 13 December 2005).

13. Police officer indicted. Alleged to have confiscated gaming machines and pocketed the money $(V G, 19$ October 2006).

14. Going to get her drunk and have his way with her. Police chief charged with sexual harassment (Dagbladet, 23 November 2007).

15. Police chief charged, urged criminal to kill colleague (Dagbladet, 20 January 2008).

16. Police officer stole weapons. Indicted by Norwegian Bureau (Dagbladet, 6 March 2008).

17. Police employee indicted; called an African ape (Dagbladet, 8 April 2008).

18. Police chiefs arrested for aggravated corruption, charged by Norwegian Bureau (Dagbladet, 19 May 2008).

19. Police officer convicted. Gave information to criminal pal ( $V G, 17$ June 2008).

In these cases, there is no doubt that the Norwegian Bureau reacted and that the cases had consequences for those involved. By no means were these cases hushed up by the media.

On television news broadcasts, the variation among cases is far more limited, which means that it is primarily the big, controversial stories that make the news. The segment of the public that watches television news but reads only small-circulation local papers, which rarely mention the Norwegian Bureau, is far less well-informed, and more one-sidedly so.

What about cases that the Norwegian Bureau endorses dropping because investigators conclude that nothing criminal has happened, or because of 'insufficient evidence'? These news stories exist, of course, but if we count the number of specific news reports on decisions not to proceed, it is - somewhat surprisingly for some - relatively small. Some examples of such news items from the two tabloids are:

20. No punishment following car chase ( $V G, 6$ July 2007).

21. No sexual harassment. Norwegian Bureau believes that the criminals may have misunderstood consolation ( $V G, 14$ September 2007).

22. Committed suicide in prison. Case dropped (VG, 24 October 2007).

23. Died in police custody (Narvik). Expert believes supervision was inadequate. Director General of Public Prosecutions will not proceed (Dagbladet, 17 December 2008). 
The impression among many members of the police force that only dropped cases make the news appears to be for a completely different reason. In a limited number of cases with wide coverage, and that were eventually dropped, suspicions or accusations of police brutality were reported. It is even worse if there is suspicion that the abuse can be tied to more general forms of discrimination, such as skin colour or national or ethnic origin. These incidents are always considered 'test cases' by the public and may, in the court of public opinion, matter far more than scores of other publicised decisions for the way the police and the Norwegian Bureau are perceived. During the period we examined, the Obiora case, to which we will now turn, is just such an example.

\section{A Death that Sparked Public Debate}

How the media prioritize, present and frame news can have political implications as well as spark debate and public protests. Media coverage of a Norwegian law enforcement action with deadly consequences can serve to illustrate this point.

On 7 September 2006, Eugene Ejike Obiora, a student at the Norwegian University of Science and Technology (NTNU) in Trondheim, lost his life following a law enforcement action. A Norwegian citizen originally from Africa, Obiora had lived in Norway for more than 20 years when he died. That day he visited a social welfare and service office in the city. While he was there to appeal denial of social assistance, the staff perceived him as threatening. ${ }^{9}$ After what was referred to in media reports as a 'scuffle' with four police officers, he was wrestled to the ground, on the stairway landing outside the service office, and handcuffed.

During the arrest, Obiora experienced difficulty breathing, lost consciousness and, still in handcuffs, was placed in a police car and driven to a hospital. At the hospital, after several attempts at resuscitation, he was pronounced dead. Regarding the cause of death, the medical experts' autopsy report stated it '[was] not possible to determine the exact time of death, but that it has to be regarded as most likely that the cessation of circulation had occurred before arrival at the hospital at 14:25, possibly already before transport to hospital took place'.

Soon thereafter, many people, particularly many immigrants and young anti-racism activists, interpreted the death as an example of unnecessary force related to Obiora's African origin. This led to public demonstrations, not only in Trondheim, but also in Oslo and other Norwegian cities. The Norwegian Bureau for the Investigation of Police Affairs, a separate legal unit under the Ministry of Justice, conducted two investigations of the case. However, just before Christmas 2007, the Director General of Public Prosecutions concluded that no indictments would be brought against the police officers involved. At the same time, the Director General's conclusion stated, 'Even though the action described was not criminal, there is every reason for the police to express regret at Obiora's tragic death.'

The decision prompted new protests. The Obiora case had become a cause célèbre symbolizing wildly divergent views on the way the police perform their societal role. In practice, we may speak of two sharply differing and competing mediated discourses on the Obiora case that strongly influenced the framing of the news stories. One discourse is established, represented and maintained by police spokespersons, police union representatives and the lawyer for the police officers involved. The other is established and represented by Obiora's family and friends, their lawyer, spokespersons for Norwegian- 
African organizations and the leadership of the Norwegian Federation of Trade Unions (LO) in Trondheim. Somewhat simplified, we can speak of a 'police discourse', closely associated with various institutional representatives of the police, and a 'racism discourse', formulated and maintained by various groups in civil society. We will briefly touch on how these discourses became established in the media and were challenged during the different phases of the case.

The police discourse is premised on the notion that the police do a vital and difficult job for society, during which, sadly, the use of force is at times necessary. The work is dangerous, and police officers on the front line may risk their lives and health. Sometimes, regrettable mishaps and accidents occur that affect the persons being arrested. Obiora's death is interpreted as a consequence of grievous circumstances. The police officers were compelled to intervene, but unfortunately, Obiora resisted so violently that, when he had to be removed from the social services office, police officers had to grab Obiora around the neck, force him to the ground and put him in handcuffs. On the other hand, the premise of the racism discourse is that the death was caused by unnecessary police brutality and that Obiora's especially brutal treatment was because of his African background. The news media's contrasting frames relate to these divergent ways of evaluating the effort and work of the police.

One of the purest examples of the police discourse is the first mention of the case in $V G$, Norway's largest circulation daily (11 September 2006). The headline was 'Fighting for their lives'. This frame was confirmed in the introduction: 'The police officers felt they were fighting for their lives when a 48-year-old died during an arrest in Trondheim on Thursday.' The primary source for the story is the officers' lawyer, who says that his clients acted in self-defence. The problem during the arrest was that Obiora put up violent resistance. 'He was awfully strong. With a jab of the elbow, he managed to fracture three ribs of one of the officers. He allegedly fought his way through the premises with an officer hanging from each arm.' Specifically, according to $V G$, it was the police officers who were 'fighting for their lives', not Obiora, who actually died.

In a later phase of the case, the head of the Norwegian Police Federation became a key representative of the police discourse. In interviews and television debates, he repeated his main talking points: Police officers who work on the front line have a difficult and risky job. While the use of force is legitimate, now and then things can go awry. In an interview with the socialist daily Klassekampen on 14 May 2007, he characterized the arrest of Obiora as 'good police work'. In the climate that the debate about the case had created, this was perceived by many as highly offensive, and a short time later, the union leader had to apologize for this statement.

This portrayal of the case stood in clear contrast to Adresseavisen's introductory front-page headline on it, 8 September 2006. '- They used a chokehold. The 48-yearold ${ }^{10}$ died after being arrested by the police.' Sources for this story were two young men who were at the social welfare and service office during the arrest. They added that the police later used a chokehold on Obiora while he lay on the ground: 'It sounded like he wasn't getting any air, and his legs began to wriggle.' The following day, 9 September, Adressavisen had a new top story on the case with the headline: 'Testifying against the police'. In this instance, the witness was a 17-year-old who said that he would report to the Norwegian Bureau for the Investigation of Police Affairs to testify that he 'saw the deceased 48-year-old being beaten unconscious, while the police had him in an iron grip'. 
Therefore, to begin with, there is the contrast between 'necessary force' and 'needless police brutality' that characterizes the news coverage. Already on 11 September 2006, Adresseavisen, the local newspaper in Trondheim, introduced a new dimension: the suspicion of racist attitudes and that Obiora was handled with brutality by the police because he was black. In an interview story, the newspaper reported that grieving immigrants in Trondheim were indignant. Those interviewed were not surprised at what had happened. One of Adresseavisen's sources, an immigrant who is a social worker with the city of Trondheim, told the newspaper that he had himself experienced being put in a chokehold and had had other unpleasant experiences with the police because of his skin colour.

This perception, that national origin and ethnicity played a role in police conduct, was quickly established as a general attitude among the many who protested the death, especially among young people and other activists involved in efforts to combat racism and discrimination. At all protests regarding the case that the press reported, anti-racist slogans and symbols played a visible and crucial role. With racism as the keyword, this interpretation was the counterpart to the police discourse.

Table 3 is based on the content analyses of all articles, in our four leading Norwegian newspapers, mentioning the Obiora case and the Norwegian Bureau for the Investigation of Police Affairs in the period immediately following Obiora's death and during the subsequent investigations and protests (8 September 2006 - 30 September 2008). To remind the reader, the four newspapers include Norway's three largest dailies, $V G$, Aftenposten, and Dagbladet, and Adresseavisen in Trondheim.

One of the examined variables pertains to the question of whether the articles are framed by a headline or introduction that directly ties Obiora's death to racism or discrimination against immigrants. Possible answers are either yes or no. A yes response requires that this angle be explicit. As Table 1 shows, such framing was clearly present in slightly less than one-quarter of all editorial content (articles weighted by their space), but with a higher percentage in the two popular tabloids, Dagbladet and VG. Political protests following the death, in particular, were given high priority in these papers. The lower percentage in the local daily, Adresseavisen, is primarily due to that paper having far more extensive coverage of the case than the national newspapers. The number of stories of this type was at the same level.

Table 3. Is the Obiora Case Directly Tied to Racism and/or Discrimination against Immigrants?

\begin{tabular}{lrrrrr} 
& \multicolumn{5}{c}{ Newspaper } \\
Racism/discrimination & VG & $\begin{array}{c}\text { Aften- } \\
\text { posten }\end{array}$ & Dagbladet & $\begin{array}{c}\text { Adresse- } \\
\text { avisen }\end{array}$ & All \\
\hline Yes & 34 & 26 & 42 & 14 & 23 \\
No & 66 & 74 & 58 & 86 & 78 \\
Total & 100 & 100 & 100 & 100 & 101 \\
$(\mathrm{~N}$ in $1000 \mathrm{~cm} 2)$ & $(21.3)$ & $(8.0)$ & $(16.4)$ & $(67.8)$ & $(113.5)$ \\
\hline \multicolumn{5}{c}{ (Cramer's V: 0.268) }
\end{tabular}

Note: Per cent of all articles (weighted by space) in which both the Obiora case and the Norwegian Bureau for the Investigation of Police Affairs are mentioned (8 September 2006 - 30 September 2008), by the newspaper. 
The Director General of Public Prosecutions did not issue his decision until Christmas 2007. The conclusion was to drop the case against the police. The police officers under investigation told the NRK evening news broadcast Dagsrevyen (22 December 2007) that they felt vindicated and were relieved at the outcome. Owing to the explosive nature of the case, their voices were distorted, and they were interviewed with their backs to the camera. During the same report, one of Obiora's friends expressed his outrage against those who 'killed him' and characterized the decision of the Director General of Public Prosecutions as cowardly.

When interpretive frames are established and tied to mediated discourses, another key factor is that the individual case in focus may be linked to related cases. A case concerning police brutality will easily provoke memories of earlier examples of the same. In addition, new incidents that attract attention may be tied to the original scandal. This also took place in the Obiora case. We shall mention two such examples here.

The first important 'linkage' was published early on and was the subject of stories in many newspapers. Adresseavisen, the local paper in Trondheim, which was the first to report this incident (12 September 2006), reported: the policeman who allegedly used a chokehold on Obiora 'had been involved in the Baidoo case', one from 1999 that attracted a great deal of attention, in which Sophia Baidoo, a woman originally from Ghana - in her work as a cleaner, set off an alarm at a bank in Trondheim that she was supposed to clean. When the police arrived, she could not identify herself and was asked to sit on a chair. When she did not comply or did not understand the request, according to Adresseavisen, a 'scuffle' ensued. The cleaner ended up in a security cell and claimed that the police officer had called her 'faens svarting' (a fucking nigger). The police officer replied that he had said 'svarte faen' (black fuck) and that she had bitten him. He was initially fined NOK 3,000 for his language, but was later acquitted in court and the fine annulled. In an interview with Dagbladet (13 September 2006), Baidoo said, 'if it's the same police officer who is involved in this incident, I'm not surprised'.

The other 'linkage' tied to the Obiora case involves a previous arrest with a deadly outcome. The death, in 2004, was of a Swedish citizen, 44-year-old Robert Michael Agoncha-Kohn. On 12 June 2007, Dagsavisen in Oslo reported that he was strangled when, during an arrest at a hotel in Oslo, the police wound an anorak hood around his head while his feet were shackled. Investigators did not find any fault with the way the police acted and decided not to proceed. After a complaint by the parents of the deceased and intervention by a Swedish lawyer, the Director General of Public Prosecutions reopened the case. The result was that the Oslo police were fined NOK 50,000. However, no one informed the victim's family of this decision.

Dagsavisen's story was picked up by a number of other news organizations. In an editorial, Dagbladet wrote (13 June 2007):

We have gradually seen numerous examples of how certain police holds are dangerous for arrestees. In the wake of the Obiora case, tests have shown that prone restraint is such a dangerous hold. Chokeholds are another. The Swedish man arrested in 2004 also had an anorak hood over his face, preventing police officers from seeing that the man's face had changed colour and that he was no longer breathing. 
The new revelation of an 'old' case not only caused a stir among the public — and renewed criticism from those already sceptical towards police methods - but also shocked many politicians. In Dagbladet (14 June), Minister of Justice Knut Storberget (Labour) was worried about public trust in the police, and the newspaper reported that he had summoned the 'heads of the Norwegian justice and law enforcement community' to an emergency meeting to discuss a handful of measures. Storberget had previously indicated his intention to evaluate the Norwegian Bureau for the Investigation of Police Affairs. Now, the Minister of Justice added that he 'also wanted a discussion of both training and instruction in the methods and holds the police use in making arrests'. The Dagbladet article reminded readers that a few weeks earlier, several thousand had taken part in antipolice demonstrations in several Norwegian cities after the Obiora case was dropped.

Taken together, there is no doubt that these 'linkages' to previous and contemporary cases helped to cement the racism discourse in the public's mind. When one particular interpretive framework becomes dominant, the news media's coverage also attaches the most importance to testimony and information that confirm the selected angle and framing.

\section{Conclusions}

In our introduction, we listed the research questions. Let us again mention them, and summarize our answers:

What kind of image of the Norwegian Bureau for the Investigation of Police Affairs is being communicated in news texts?

Answer: In many of the cases examined, a critical perspective on the work of the police is - as expected - being communicated. After all, it is just such cases that the Norwegian Bureau was set up to handle. On the one hand, the result is drawing public attention to the dark side of the police, but this largely relates to individual cases and episodes concerning 'bad apples' in the service. The emphasis is primarily on individual deviations from and violations of standards, not systemic features and organizational culture. Of such reasons, we cannot speak of a single media image of the Norwegian Bureau. In a number of articles, the unit is portrayed primarily as an investigative body that 'gets to the bottom' of cases where the police service as a whole or particular officers have violated laws or guidelines. In the sense that the Norwegian Bureau is portrayed as an institution that is supposed to clean things up and is willing to deal with inequities, this image is partly neutral and partly positive. While there are many such cases, they are seldom of long duration, and only limited attention is paid to each one.

The competing media image is primarily associated with the Obiora case and a few other news stories. The lasting impression is that investigators with police backgrounds still are allowed to investigate former colleagues, with the bar set high for the Norwegian Bureau to prove any wrongdoing.

How extensive and systematic is the coverage of the Norwegian Bureau and its cases in the press and on television?

Answer: Although the coverage is in some periods and cases extensive, it is not systematic. None of the media organizations studied in this period cover the Norwegian Bureau regularly or as a permanent part of a dedicated 'news beat'. 
Which groups are the predominant types of sources in these news reports?

Answer: The 'official sources' from the police, prosecuting authorities and the Norwegian Bureau play the leading role, in most cases supplemented by lawyers. The protests after the death of Obiora created a special case because of the representation of grassroots protests in the news. Politicians generally play a minor role.

What kind of complainant primarily receives media coverage?

Answer: This study does not support the hypothesis that complaints given press coverage are largely those filed by criminals/offenders out for revenge. In general, there are very few cases in the material with such sources.

Is it primarily the Norwegian Bureau's decisions not to proceed and acquittals that receive public attention?

Answer: The news media regularly report the Norwegian Bureau's investigations and criminal sanctions, which reinforces the image of an investigative and prosecutorial body that is willing to clean things up. In general, it is not the Bureau's dropped cases that primarily attract attention. The press regularly covers various kinds of sanctions against the police. The exception to this is the Obiora case and a few other examples of police brutality or negligence.

What discourses characterized public debate on investigations of the police and activities of the Norwegian Bureau during the period 2005-2008?

Answer: The predominance of the Obiora case in the news reporting and the public debate from 2006 to 2008 made accusations of racist attitudes in the police into an influential discourse, especially because this example could be linked to other stories of the same kind. This discourse dominated the public space and the legal discourse. When the case was being dropped just before Christmas 2007, many who were interested in it viewed this as a confirmation that institutional racism is still silently accepted. At the same time, the public moral indignation was overwhelmingly aimed at demands for individual punishment and atonement and less at whether features of the organizational culture, recruitment and training in the police service contribute to abuses and tragedies. Viewed in this way, the critical media reporting suffers from the same political limitations that generally characterize media crusades in person-oriented, political scandals (Thompson 2000; Lull \& Hinerman 1997; Allern \& Pollack 2012). They mobilize our indignation, but contribute little to reflection and new insights.

Who guards the guardian? The problem of how to police and control the police themselves - and by whom this should be done - is an old one (Reiner 2010: 26). The police institution has the formal responsibility for use of legitimate force to safeguard security and deal with conflicts in modern society. As one party's security may be another party's repression, the police as an institution require broad public legitimacy. We have to believe that the police are working for the common good, that they are efficient enough and that there are ways to minimize any misuse of their power. Voters' main source of information about this is the news media, which play a principal role in shaping the public image and impressions of how the police institution functions, and of whether the authorities who investigate the police can be trusted. 
Studies have shown that the news media do not conduct any regular supervision of the police as a societal institution (Pollack 2008, Surette 2011), nor do they, if we assume that this study shows a general pattern, cover the authority that investigates and governs the police - here the Norwegian Bureau - in a systematic way. The media's news coverage of the police and the investigators of the police is in most cases eventdriven. Single events, often with violence as an ingredient, guide journalistic coverage. However, these events - which may very well deserve attention and be of public interest - thus give us an accidental and one-sided picture of the problem. Moral indignation over single cases and "rotten apples" in the police force prevent us from analysing institutional and organizational shortcomings. Because broader perspectives are absent, the picture of the police seldom points to institutional or organizational problems. The story is too often one about individual wrongdoings alone. Unfortunately, such media pictures matter and influence policy decisions, especially when they become the point of departure for political debate - as we have witnessed many times before in the field of crime and policing.

\section{Notes}

1. A Swedish study (Heber 2007) confirmed that people, when asked about their understanding of crime development and risks, refer to the media as the main source of their information.

2. The Bureau only handles complaints from the public that amount to a criminal offence. It is not a case for the Bureau if a police officer commits a crime when he/she is off-duty; this will be left to the police to handle.

3. On November 11, 2011, the name of the ministry was changed to the Ministry of Justice and Public Security.

4. Liv Finstad, Professor of Criminology, University of Oslo, headed the commission.

5. We thank Elin Hornnes Strand for her competent assistance with the coding.

6. All translations of Norwegian news text citations to English are our own.

7. The debate programmes are the TV2 programme Tabloid (7 May 2007), RedaksjonEN on NRK (13 June 2007) and Standpunkt on NRK (18 September 2007).

8. A standard tabloid page is approximately 900 square $\mathrm{cm}$.

9. The information in these introductory paragraphs is based on the Office of the Director General of Public Prosecution's petition in the Obiora case, 21 December 2007.

10. Despite his age of 48 , Obiora was registered as a student at the Norwegian University of Science and Technology (NTNU) in Trondheim.

\section{Bibliography}

Allern, S. (2001) Nyhetsverdier. Markedsorientering og journalistikk i ti norske aviser. Kristiansand: IJforlaget.

Allern, S. (2014) When journalists frame the news. In Fahlenbrach, K., Sivertsen, E. \& Werenskjold, R. (eds.) Media and Revolt. Strategies and Performances from the 1960s to the Present. New York/Oxford: Berghahn Books.

Allern, S. \& Pollack, E. (2009) Mediebilder av politikritikk. En analyse av hvordan sentrale nyhetsmedier har dekket Spesialenheten for politisaker 2005-2008. Appendix 5 of Official Norwegian Reports, (NOU) 2009: 12, Et ansvarlig politi. Apenhet, kontroll, laring.

Allern, S. \& Pollack, E. (eds.) (2012) Scandalous! The Mediated Construction of Political Scandals in Four Nordic Countries. Gothenburg: Nordicom.

Carlson. M. \& Franklin, B. (2011) Introduction, in Franklin, B. \& Carlson M. Journalists, Sources and Credibility. New Perspectives. London: Routledge.

Chibnall, S. (1977) Law-and-Order: An Analysis of Crime Reporting in the British Press. London: Tavistock Publications.

Dahlgren, P. (1987) Pressens bild av brottsligheten. Stockholm: BRÅ: information.

Davies, N. (2009) Can the police and the media trust each other? The Guardian, Monday 27 April 2009. 
Entman, R.A. (1993) Framing: towards clarification of a fractured paradigm, Journal of Communication, Vol. 43 (4): 51-58.

Ericsson, R., Baranek, P. \& Chan, J. B. L. (1989) Negotiating Control: A Study of News Sources. Milton Keynes: Open University Press.

Filstad, C. \& Gottschalk, P. (2011. Performance evaluation of police oversight agencies. Policing and Society: An International Journal of Research and Policy, 21:1, 96-109.

Gottschalk, P. (2011) Police misconduct behaviour: An empirical study of court cases. Policing, Vol. 5, Number 2, pp. 172-179.

Heber, A. (2007) Var rädd om dig! Rädsla för brott enligt forskning, intervjupersoner och dagspress. Stockholm: Kriminologiska insitutionen, Stockholms universitet.

Høst, S. \& Bodahl-Johansen, G. (2001). Kulturforskjell og tilpasning: Journalisters forhold til politi, påtalemyndighet og domstoler. Fredrikstad: Institutt for Journalistikk.

Jewkes, Y. (2011) Media and Crime. London: Sage.

Lull, J. \& Hinerman, S. (1997) Media Scandals. Morality and Desire in the Popular Culture Marketplace. Cambridge: Polity Press.

Marsh, I. \& Melville, G. (2009) Crime, Justice and the Media. London: Routledge.

Mawby, R.C. (2010) Chibnall revisited. Crime reporters, the police and 'Law-and-Order News'. British Journal of Criminology, 50, pp. 1060-1076.

Mawby, R.C. (2012) Crisis? What crisis? Some research-based reflections on police-press relations. Policing, Vol. 6, Number 3, pp. 272-280.

NOU 2009: 12. Et ansvarlig politi. Apenhet, kontroll og laering (Official Norwegian Report 2009: 12. A Responsible Police. Openness, Control and Learning).

Pollack, E. (1995) Bovar och bomber: om relationen mellan skildrare och bekämpare av den folkhemska brottsligheten in Ekecrantz, J., Olsson T. \& Widestedt, K. (eds.) Nittonhundrafemtiofem. Journalistiken och folkhemmet. Skriftserie 1995:2: Stockholms universitet.

Pollack, E. (2001) En studie i medier och brott. Stockholm: JMK, Stockholms universitet.

Pollack, E. (2008) Medier och brott, in Granhag, P.A. \& Christianson, S.Å. (eds.) Handbok i rättspsykologi. Stockholm: Liber.

Reiner, R. (2011) The Politics Of The Police. Fourth Edition. Oxford, New York: Oxford University Press.

Surette, R. (2011) Media, Crime, and Criminal Justice. Images and Realities. Belmont, CA: Wadsworth.

Thomassen, G. (2002) Investigating complaints against the police in Norway: An empirical evaluation. Policing and Society: An International Journal of Research and Policy, 12:3, 201-210.

Thompson, J. (2000) Political Scandal. Power and Visibility in the Media Age. Cambridge: Polity Press.

Van Gorp, B. (2007) The constructionist approach to framing: Bringing the culture back, Journal of Communication 57 (1): 60-78.

ESTER POLLACK, Ph.D. , Associate Professor, Department of Media Studies, Stockholm University, ester.pollack@ims.su.se

SIGURD ALLERN, Ph.D. Professor, Department of Media Studies, Stockholm University, sigurd.allern@ims.su.se 